\title{
2
}

\section{Currents and perspectives in contemporary civilisational analysis}

The previous chapter explores the context in which civilisational analysis revived in the humanities and social sciences. The key contention is that contemporary historians and comparative sociologists have posited integrationist, processual and relational images of civilisations. The three images apply to a more diverse range of viewpoints and perspectives than prevailed in earlier studies of civilisations in anthropology, archaeology, history and sociology. In this chapter, those images are profiled and interrogated. As a whole, the chapter aims to articulate the insights and limitations of each image by setting out how each shapes approaches to civilisations. Along the way, I pose questions about how open each particular image is to analysis of the creation of interactivity. The images are represented, respectively, by the work of Eisenstadt, Elias and Arnason. By exploring how each problematises, historicises and compares civilisations, the achievements of the contemporary scholarship of civilisations can be critically assessed. Once the current limits of the field are established and the critical counterpoints of competing paradigms assessed - the task of Chapter 3 - it then becomes possible to explore in greater depth an innovative way of framing the study of civilisations as inter-civilisational engagement, specifically migration, economic relations, cultural exchange and the re-creation of models of civilisation.

Given that post-war contexts laid the groundwork for the manner in which contemporary civilisational analysis would be shaped as a paradigm, more explanation on this period is required prior to examination of the three images. Before the twilight of the Cold War created conditions for the resurgence of civilisational analysis and the proliferation of perspectives, the marginalisation of inter-disciplinary and multidisciplinary studies of civilisations by the modernisation paradigm favoured the integrationist image and a more homogeneous field. Modernisation studies and area studies seized the spaces of Western history, sociology and politics that might have otherwise been occupied by civilisational 
analysis. Modernisation studies served Cold War objectives in the political climate of superpower rivalry, when the multidisciplinary and inter-disciplinary research agenda on civilisations could not (Cox, 2002: 139). In addition, civilisational analysis was at odds on key points with the socio-centric and methodologically nationalist mainstream, which in the post-war period was preoccupied with national histories and national societies. In highlighting the different developmental paths of many civilisations, a minority current of sociologists, historians and archaeologists resisted the trends in modernisation and area studies towards a dominant narrative of societal evolution. They did so from the margins of their disciplines. However, civilisational analysis - such as it was in the 1960s and 1970s - mirrored modernisation and area studies in other minor ways. The prevailing focus of the modernisation paradigm on society as a relatively discrete unit of research had an equivalent in civilisational studies. That equivalent lay in the conceptual cast of civilisations as discrete and internally transformative socio-cultural entities, rather than an interactive model of overlaps and interconnections of civilisations.

Modernisation theory reached its apogee in the context of the Cold War and the end of Europe's empires; that is, when the declining hegemony of the Western European powers became so clearly observable that it could no longer be denied. Decolonisation had two consequences in this respect. First, the rise of new nation-states resulted in a Third World contrasted with the wealthy and mostly Western First World. Second, new migratory movements emerged as a consequence of colonialism and were continued as repercussions of neo-colonial influence and interference in the affairs of new post-colonial states. For Britain, France, the Netherlands and then Portugal, new migrants from the former colonies gave their economies new sources of manual labour (Castles et al., 2014: 108-11). Together, both consequences served to undermine mainstream accounts of society and culture that neglected the diversity of civilisations, cultures and economies that defined the lives of a majority of humanity.

The Cold War also shaped modernisation theory's fortunes and fates. As the United States assumed leadership of the West, the burden of social scientific knowledge of new Third World societies was claimed for American modernisation analysis and made a policy priority of a succession of US governments from Truman through to Johnson. Large research grants from public funding bodies and private philanthropic foundations buttressed the development of modernisation studies led by Talcott Parsons, Edward Shils, Daniel Lerner and others. Under the influence of Parsons' sociological programme of study of evolutionary universals, modernisation theory developed a typology of modernity and tradition. Though it dichotomised many diverse societies, the typology also presupposed developmental potential for all societies whereby they would 
emulate a single model of modernity. The rapid shift from a world of empires to an international arena of nation-states put questions of convergence, reform and development on the agenda. Meanwhile it forced the Western social sciences to empirically confront the fullness of collective experiences previously subsumed by colonialism. Under these circumstances, attempts from within the modernisation paradigm to reconcile palpable divergence in developmental paths and diversity of societal forms with a meta-narrative of convergence made the paradigm unviable and unjustifiable (Wagner, 2014). Moreover, the modernisation paradigm found itself incapable of responding to new critiques by theorists in world systems analysis and dependency theory who posited enduring and new forms of domination. The critique of modernisation as a category demonstrated how inadequate the paradigm was for the functions it was called into being for.

The rise and decline of modernisation theory dominated the social sciences to such an extent that space for alternative paradigms was cramped. One way to think about the fortunes of civilisational analysis in these decades is in terms of 'generations', as Tiryakian (2004) and Arjomand (2014b) do. Comparative sociology and civilisational analysis can be divided into three generations of scholars. The first features in the opening chapter. The second generation conducted scholarship in the downturn of modernisation theory. Melko and Scott (1987) show how civilisational analysts of this generation sustained analytical schemes developed by Rushton Coulborn and Carroll Quigley after the Second World War. What did the schemes look like? Quigley's was typical. For Quigley, civilisations congeal around dynamics of expansion and accumulation (1979). The requisites of civilisation are order and law, long-distance trade, growth of cities, presence of a middle class, and literacy (1979: 266). In sequences of ascendancy, crisis and expansion, civilisations undertake either '(1) reform, (2) circumvention, or (3) reaction' via cultural and technological adaptation (1979: 144). The fates of civilisations are determined in such responses. Quigley's concept of seven successive stages of development attempts to reconcile history and evolution. When civilisations decline, resources for expansion come from succeeding peripheries. In this manner, the evolution of many civilisations tracks previous patterns: Greece emerged from the edges of Minoan civilisation, Islamic civilisation arose on the eastern periphery of classical civilisation, and so forth.

Classificatory models like Quigley's circulated within the International Society for the Comparative Study of Civilisations, founded in 1961 by Benjamin Nelson, Othmar Anderle and Vytautas Kavolis (Melko and Scott, 1987: 1-3; Robertson, 1992: 3). The Society sported high-profile intellectual leaders. Pitirim Sorokin was its first president. When the Society relocated to the United States in 1970, Benjamin Nelson took over the role. Other eminent scholars associated with the Society include Parsons, Toynbee, Immanuel Wallerstein, Kroeber, Andre 
Gunder Frank and Marshall Sahlins. High-profile figures did not result in greater impact in the early years of the Society, despite the energetic efforts of its founding generation. However, according to available accounts, the Society has been a lively debating society. Its members have concerned themselves with methodological and epistemological controversies, analysis of components of civilisations and acting as a clearing house of definitions and perspectives. In the course of the Society's life, many scholars continued in the integrationist vein of the histories of the interwar years. With the passage of time, varying aspects of the vitality of civilisations have become more prominently represented, and the field has become more inclusive of different indices.

Such was the second generation. For the third generation, Arjomand nominates Marshall Hodgson, Nelson, Eisenstadt, Donald Levine, Edward Tiryakian, Eliezar Ben-Rafael, Arnason, Bjorn Wittrock, Luis Roniger, Bernhard Giesen, Sheldon Pollock and Georg Stauth (Arjomand, 2014b). Eisenstadt, Levine and Tiryakian stand out as reconstructed modernisation sociologists who lived through its peak era and who have subsequently adopted post-functionalist positions. Also, the critical dialogue they engaged in with modernisation studies conditioned their subsequent trajectory. If international relations scholars were added, Peter Katzenstein would be in the lead, with Brett Bowden, Martin Hall, Patrick Jackson, Robert W. Cox, Sadik Unay, Muzzafer Senel and Pavlos Hatzopoulos following. Others could make the list, including the proponents of the call for a Dialogue of Civilisations, such as Fred Dallmayr, Michalis Michael and Fabio Petito.

The group identified by Arjomand are defined by their problematisation of early-twentieth-century perspectives on civilisations and a high level of debate about new propositions. International exchange around different theories, applications of methodology and epistemology and substantive findings have driven contact and dialogue. Eisenstadt's coordination of a large multidisciplinary network in coherent research around Axial civilisations, multiple modernities, Islam, collective identities and the public sphere put him at the epicentre at different times. The same is true of Tiryakian and Arnason at different points. Collaboration and debate have been watchwords in international relations also. A common scholarly public engaged through conferences, publications and personal communication has added to a larger 'conversation' around contemporary civilisational analysis. Researchers who foreground early modernities cooperated in a similar manner. That particular research path seems to have petered out after 2005, however, with a lack of consensus about 'when' early modernities coalesced. The field came to be dominated by problematics of multiple modernities and process-based comparative analyses. The perspectives of Eisenstadt and Elias are the most representative of, respectively, integrationist and processual 
images of civilisations. The most prominent image in Arnason's work is the relational one, the current closest to the model of analysis expounded in Chapter 4 and Part II of the current work. A critical précis of Eisenstadt's and Elias's chief contributions shows gaps in their models of civilisational sociology, as well as, in Arnason's case, directions for conceptual reconstruction.

\section{Eisenstadt's comparative civilisational analysis}

Eisenstadt's leadership in the revival of the overall field makes him a seminal figure. In the 1990s, he spearheaded major research enterprises defining the agenda for contemporary civilisational analysis. Along with Tiryakian, Eisenstadt steadily changed his substantive focus to civilisations as part of 'a long march of reckoning with modernisation theory' (Salvatore, 2006: 279). In this shift, his comparative sociology entailed critical continuity of an integrationist image of civilisations. As a result of that process, Eisenstadt and Tiryakian came to emphasise social dynamics and the study of empires, modernities and civilisations in place of 'society' as the unit of analysis (Eisenstadt, 2000a; 13-17; Tiryakian, 2004). How does Eisenstadt define civilisation? In one place he describes civilisations in the strongest integrationist terms possible, posing them as discrete 'areas and sequences' (2001: 1915) in a conception 'very close to, but distinct from' naming them as 'socio-cultural units' (2001: 1916). In fact, he has other answers to the question also. However, there is one clear statement made in a programmatic essay that seems the most representative. Civilisation is 'the combination of ontological or cosmological visions (visions of trans-mundane and mundane reality) with the definition, construction, and regulation of the major arenas of social life and interaction' (2000b: 2). As a programme of research into cultural ontologies, he organises his comparative sociology around three problematics: Axial civilisations, multiple modernities and the civilisation of modernity (Delanty, 2004: 393). Each is examined sequentially here.

Chronologically, Axial civilisations came into view first. Picking up on insights into the significance of human evolution in this era from Karl Jaspers, Benjamin Schwartz and Eric Voegelin, Eisenstadt extended the problematic of the Axial Age beyond the first millennium BCE (Eisenstadt, 1986). Following Martin Buber's proclivity for multidisciplinary investigations into creativity, he coupled philosophical notions of axiality with Weber's comparative sociology of worldly orientations and came up with 'Axial Age civilisations', in which a creative tension between transcendental and mundane orientations crystallised. Put simply, the first signs of philosophical reflection on the nature of the cosmos, matter and materiality and being, and social, economic and political life emerged across 
Eurasian societies during this time. In different Axial civilisations, cultural ontologies crystallised with new kinds of reflexivity. There was greater scope in these new social orders for interpretation and questioning about the terms of human conduct and the norms of social life. Doctrines and ideologies were consolidated as a result of the epistemological breakthroughs made. In other words, particular transformative ideologies were instituted along with the means of continuity of knowledge, new forms of collective memory and identity. Knowledge could be written down, reproduced, passed on and passed down, its contents critiqued and its categories and second-order questions subjected to debate. In all, knowledge could be consciously transformed.

Eisenstadt renewed interest in questions of the Axial Age. His original contribution was to assemble specialists from history, sociology, classical studies, linguistics, philosophy, religious studies and sociology to develop a collaborative multidisciplinary research programme that could set civilisation as the consummate plane of all social orders (Arnason et al., 2005; Eisenstadt, 1986). For Eisenstadt, the gulf between the ontological conception of higher and lower orders of existence produces the conflicts of social life that become the dynamics of development and the basis for long-term developmental paths. A sharp focus on transcendence and the world religions defines his approach to civilisations in this register of analysis. The Axial paradigm thus, refined, becomes a different lens through which to view and understand problems familiar to neo-Weberian sociologists: structural differentiation; coalescence and agency of intellectual elites; access to and participation in the decision-making of states; religious schism and movements of protest; and social action shaped by the balance of worldly and transcendental religious ethics (Eisenstadt, 2002a: 256-64).

Questions about the historical sociology of Axial civilisations surfaced in the 1990s and prompted ongoing discussion (Arnason, 2015; Arnason et al., 2005; Bellah and Joas, 2012). There is no space here to explore the myriad paths of the subsequent debate. But one criticism can be foreshadowed. At no time has any systematic attempt been made to bring other non-Axial zones into the picture (with the one exception of Japan) to defend the Axial civilisations thesis. If that step were systematically taken, then Eisenstadt's conception of civilisation and its dimensions would be further problematised and questions would emerge about modern empires as states. To take that step would require reformulation of the initial typology of Axial civilisations in order to incorporate major societies for which the crucial developments occur after the Axial Age. But this would raise further doubts about the categories of transcendental and worldly orientation to different civilisations across Eurasia.

The second problematic is his concept of multiple modernities (Eisenstadt, 2000a). Eisenstadt has not been alone in infusing the concept of modernity 
with a consciousness of multiplicity. Gaonkar's alternative modernities (1999), Jan Pieterse's 'new modernities' (2010) and Therborn's four roads to modernity are different projects on the many forms of modernity (Therborn, 2003). One clear benefit that can be claimed for pluralism is that it avoids many of the pitfalls of theories that evoke a one-world scope of analysis, such as world systems theory and cruder specimens of globalisation studies. Immediately, an analytical difficulty emerges (Wittrock, 2000): how many modernities can there be? In response, some critics of the idea of multiple modernities have backed a model of global modernity while recognising real variation (Domingues, 2012). Eisenstadt's perspective is distinguished in this field of unfolding pluralities by the manner in which he delimits the number of modernities by the cultural ontologies of many civilisations. For Eisenstadt, if there is a special source of cultural ontologies, it is the world religions. In other words, his answer to the question of 'how many modernities?' is that the world religions define the number of cultural ontologies, thereby demarcating the multiple modernities.

As multiple modernities are conceived as spatially distinct entities, one would imagine that there would be clear continuities between the research programme around Axial civilisations and the paradigm of multiple modernities. Commenting on the continuities, Knöbl argues that path-dependence is implicit in identification of core premises of modernity with the Axial tensions laid down in antiquity (2006a: 219-20). However, there are two crucial discontinuities between the literature on Axial civilisations and the research into multiple modernities. The discontinuities entail a problematic methodological shift. Revisionist histories of axiality emphasise inter-connectedness, while the paradigm of multiple modernities structures studies of separate constellations (Wagner, 2012: 153-4). The linkages that were formative for civilisations of the Axial Age are diminished in the separation of constellations of modernity. This is a critical point of distinction between integrationist and relational approaches, and also the model advocated in these pages of inter-civilisational engagement. Observing the discontinuity between the Axial civilisations and multiple modernities theses, Wagner urges advocates of multiple modernities to "place less emphasis on the separate and different origins of the cultural programmes, and consequently some diversity between contemporary modernities, and ... focus instead on the long-term interconnections in world history' (2012: 154). Wagner isolates an underlying shift from inter-connection to detachment in the work on civilisations, which is unquestionably an obstruction to clarifying questions, debates and findings.

This is one issue and it is a crucial one for the purposes of the current argument. In an effort to avoid Eurocentrism - a second issue - Eisenstadt specifies heterogeneity, divergence and polycentricity in social formations as the principal objects of analysis (Eisenstadt and Schlucter, 1998). What results is a qualified pluralism 
that struggles with the questions of the origins of modernity. The question of which modernity and which programme emerged first is a vexing one from the outset. In setting bearings for the multiple modernities paradigm, Eisenstadt and Schlucter affirm that the balance of diffusion of the original cultural programme of Europe and indigenous elements of creativity in other modernities is an empirical question. In their words, it is essential to treat the developmental dynamics of each civilisation 'not only in terms of approximation to the West but also in their own terms' (1998: 7) in order to adequately demarcate the multiple modernities. This might open the door to investigating the linkages that blend external and local models of thought, polity, economy and organisation and how forms of power are interspersed throughout different dimensions of instituted social life. Yet, at the same time, Eisenstadt reiterates the argument that Europe is the first modernity with the prototypical cultural programme. An alternative to notions of globalisation and global modernities forms with this qualification, yet it is not one that captures the relational character of the imaginary institution of multiple social formations and civilisational constellations. To be sure, Eisenstadt's framework is premised on acute awareness of pluralities. Rejecting theses on hybridisation, Eisenstadt focuses on 'how different collectivities define themselves in different ways with respect to the common problematic of modernity' (Delanty, 2004: 397). He sees this as a continuous reconstruction of the West's premises in particularly innovative developments. Other modernities have constantly redeveloped the premises of European modernity, starting with the Americas (Eisenstadt, 2002b). But the invisibility of connections between formations of modernity is too prominent to disregard. The partition of the units of analysis in the multiple modernities paradigm is at the root of this. A tension therefore exists between the commitment made to plurality and the a priori premise that the West's cultural programme is pre-eminent. Post-colonial sociologists believe this to be an unacknowledged Eurocentrism that structurally conceals the interconnectedness of social formations (Bhambra, 2007: 56-79; Boatcă and Costa, 2010; Patel, 2013). They pinpoint the isolation of the units of analysis, as others have also. The a priori assumption of geo-cultural unities characteristic of area studies scholarship is a very clear difficulty for theorising multiple modernities. The explicit agenda of multiple modernities has to compete with other models of plurality in modernity. If it is to have force in a crowded field of explanations, it will need to redress the problems raised here. It is hard to see how this could be done without returning to the problematic of connectivity of civilisations and the connectivity of modernities.

This touches on Eisenstadt's third problematic, which he launched later in his career. His notion of the civilisation of modernity flows from his singularisation of the Western European modernity as the original programme (Eisenstadt, 
2002b: 28) and its self-transforming expansion into the Americas, Central and Eastern Europe, and then to the world at large (Eisenstadt, 2004). In his theorisation of the civilisation of modernity, his perspective edges closer to the globalisation paradigm. Through multiple reinterpretations and the development of institutional patterns from those reinterpretations, Western modernity grew to become a world 'civilisation of multiple modernities' (Arjomand and Tiryakian, 2004b: 3). From where Eisenstadt stands, it looks as though the elaboration of the Axial tensions in the modern age is leading to an ecumenical civilisation of modernity in which traditions are mobilised as interpretive resources. The civilisation of modernity's Great Revolutions are the bridges from the axialities previously theorised by Eisenstadt and others to the multiple modernities, which are instituted in the world regions formerly dominated by Axial civilisations. Democratic, radical and totalitarian solutions to core modern problems all have roots in the Axial tensions reinstituted in the Great Revolutions (Eisenstadt, 2004), suggesting path dependence of the kind highlighted by Knöbl. Furthermore, some civilisations - in reaction to the civilisation of modernity - seem to Eisenstadt to be generating new and self-evidently authentic universalisms.

On these points, Eisenstadt's third problematic resembles a response to the globalisation thesis, rather than a dissention from it (Spohn, 2011: 293-7). His conception of the 'civilisation of multiple modernities' turns on a unique dialectic of universal and particular consciousness compatible with more complex renditions of globalisation. Admiring this image of globality, Robertson highlights how Eisenstadt's sociology renders 'the importance of the Axial Age as foundational with respect to ... the multidimensional globalization process' (Robertson, 2011: 308). Consciousness, a set of legacies from the Axial Age, vacillates between globality in different dimensions of social life - 'the world scene' (Robertson, 2011: 309) - and distinctive modern civilisations. The contrast is so great that it did not take much for Katzenstein to relabel the notion as the 'global civilisation containing multiple modernities' (2012b: 226). Compared with Katzenstein's strong conception of interaction between civilisations, Eisenstadt's contemporary civilisational analysis looks to have illuminating moments, but lingering difficulties in explanation.

Katzenstein's assessment of the relevance of the theory of multiple modernities alludes to the third problematic in Eisenstadt's oeuvre. The question of the 'civilisation of modernity' that Eisenstadt poses forces contemporary civilisational analysis to gain some purchase on issues of the present and prospects for the future. On the whole, it appears that comparative sociology has more difficulties grappling with civilisations in the present than perspectives in international relations, which focus on the twenty-first century (Hall and Jackson, 
2007; Katzenstein, 2010a, 2012a; Unay and Senel, 2009). Eisenstadt's specific attempt to reconcile the crystallisation of reflexivity in Axial civilisations with modern consciousness in the civilisation of modernity is the least well-developed and least convincing area of his comparative sociology. Indeed, this line of argument in civilisational analysis equivocates on the relationship of modernity to civilisations. As Arnason points out, Eisenstadt seems particularly undecided between attribution of modernity to adaptation of the Western model of selftransformation and a supra-cultural civilisation of modernity (2003: 173-4). Eisenstadt's explanation of the civilisation of modernity struggles to establish lineages of modern reflexivity going back to Axial articulations of transcendence, so much so that he hypothesises a Second Axial Age to describe modernity. The most that can be achieved is identification of comparable tensions defining the social and cultural premises of varying social orders. The tensions produce openness, antinomies and fragility as democratic visions of modernity compete with totalitarian and Jacobin ones (Eisenstadt, 1999a). Both visions draw on civilisational legacies, as well as the trans-national cultural and political programme of modernity. A global civilisation of modernity is therefore both less and more than the civilisations that precede and coexist with it (Arnason, 2003: 324-5). On one hand, modernity as a supra-civilisational imaginary erodes civilisational legacies under the logics of capitalist globalism and rationalisation. On the other hand, the social and cultural premises of civilisations dynamically effect the very cultural and political programme of modernity. Eisenstadt did not clarify the exact nature of the trans-national civilisation of modernity. Where does this leave the world religions, which are unquestionably modern in his view? What is the relationship to his problematic of multiple modernities? The questions are not adequately resolved in Eisenstadt's later writings. To reformulate them as the productive tensions of modernity leaves only questions for others to take up.

\section{Eisenstadt's comparative civilisational analysis in retrospect}

A conflation of religion and civilisation lingers in Eisenstadt's comparative civilisational analysis. The imprint of Weber's sociology of religion is still visible, even if some of the blockages in the Weberian sociology of religion have been overcome (Katzenstein, 2010b: 15-17; Spohn, 2006: 14-16). The world religions originating in the Axial Age, in Eisenstadt's view, animate civilisations as changing traditions in the modern world (Domingues, 2012: 20-3). By sharpening preliminary insights made by Weber, Eisenstadt sets religion at the heart of the civilisational premises of order. Meaning is then constructed as an overgeneralisation of Axial hypotheses to a variety of developmental patterns (Arnason, 
2003: 236-7). Ultimately this risks the charge of culturalism with which critics pummel civilisational analysis. Moreover, religious movements and theocratic elites are accorded especial agency as a consequence of the defining influence conferred on religious visions. A path-dependent logic of development is implicit in the connections made by Eisenstadt between the constitution of Axial tensions and current-day multiple modernities, yet the contingent processes that facilitated continuity are not adequately established (Knöbl, 2006a).

Eisenstadt's estimation that religion furnishes meaning at the roots of human existence as well as informing civilisational orientation and political action is an influential argument amongst his many interlocutors. However, the anomalies of the Axial Age paradigm are still hard to wish away. The civilisation that most closely integrates religious and civilisational coherence is Islamicate civilisation, which was not included in early debates about axiality. When religious coherence is overstated, other aspects of civilisational development can be overlooked. A few examples help illustrate the point. For instance, the logics of imperial expansion are not adequately related to successful campaigns of proselytism (Spohn, 2010: 59). Nationalism, which should figure as a modern feature of civilisations, stands neglected (Arnason, 2003: 61-2). In Eisenstadt's perspective, for instance, religious traditions constitute modern patterns, rather than resisting them - an important and well-argued insight. However, much the same can be said also for scientific, political and philosophical traditions that are differentiated from religious traditions. For example, the imaginary significations that furnish Western societies with conceptions of materiality as pre-classifications of the biosphere are indispensable to the institution of the sciences. The perception of materiality had origins in scepticism, materialism and idealism in the Mediterranean's antiquity. Another reference point, ancient kingship, embodies a nucleus of sacred and political power in the historical studies of civilisations that inform Eisenstadt's theory. But treating the problem of political power in the modern world is a different matter and one that demands a wider span of imaginary reference points. On the whole, as Arnason has more recently argued, the problematic of power as constitutive of civilisations is neglected in Eisenstadt's explanatory framework (Arnason, 2015).

Related to Eisenstadt's construction of civilisational analysis out of the sociology of religion is an under-estimation of the interaction of civilisations, especially in the constitution of multiple modernities. Significant insights from the published research in early modernities were not fully carried forward into the multiple modernities paradigm. Early modernities outside Europe emerged from processes of instituting inter-connections through which they co-instituted themselves. Articulation of trans-regional and consubstantial connections in this body of research is based on unequivocally post-Orientalist perspectives 
(Katzenstein, 2010a: 16). Moreover, where civilisational analysis continued to work on this problematic - particularly on Eurasia-wide processes (Arnason and Wittrock, 2004) - the balance of connections, divergences and breaks continued to be debated. The opportunity to empirically elaborate relationships between early modern linkages and latter-day figurations is lost in the absence of comparison of modernities across historical time (Wagner, 2012: 64-73, 2014: 294-5).

In this section, I have provided an obligatory summation and evaluation of Eisenstadt's key problematics. He played an indispensable part in reviving and sponsoring civilisational analysis. For this reason alone, his work deserves to be considered and here it is critically discussed as representative of the integrationist image of civilisation. The processual image is a contrast that puts into question important aspects of the projects led by Eisenstadt. Norbert Elias's historical sociology is a way of marking out some contrasts with Eisenstadt's integrationist analysis.

\section{Elias and the civilising process}

The premise of Elias's scholarship of civilisations is that there are civilising processes, rather than civilisation per se. Elias's historical sociology of the civilising process reconstructs the emergence of social constraint towards self-constraint in observable daily habits and behaviour over the course of the long European Middle Ages (Elias, 1978, 1982). Part-trained by Alfred Weber, he uniquely reformulated Max Weber's sociological categories. He then uniquely historicised them. In doing so, he produced a genealogy of the transformation of violence, which addressed the same problem of the brittle threshold of civilisation that Freud did, but which brought in sociological method and historical sensibilities. He applied a theory of 'the civilising process' to the very long temperament of violent and uncensored behaviour. Elias crafted a historical sociology of the advancement of a threshold of shame that paired the uneven civilising of affects with the coalescence of modern power (Rundell and Mennell, 1998: 25-7). For Elias, forms of civility developed in concert with two tendencies. First are the centripetal and centrifugal movements in the figuration of power, or the impulses towards centralisation or devolution of the state and its agents. In other words, the temperament of general behaviour occurs alongside the expansion of taxation, confinement of the legitimate use of violence to military forces and the creation of rationalised administrative organisations. The second tendency is the monetarisation of economic life. In urban bourgeois culture, trade, the division of labour and the use of money, outward expressions of tempered behaviour supplanted the combination of explicit violence with the structuring of economic 
life. Moreover, monetarisation enabled large-scale taxation, a precondition of centralised governance. Each tendency was dependent on the other.

The emphasis on process was not all. He developed a relational notion of power well before Foucault or Bourdieu did (Arnason, 2015). Power is not a quantified capacity waiting to be seized, but rather is intrinsic to the interaction and conflict of groups, classes and elites. State monopolies on legitimate coercion and taxation did not emerge through the accumulation of power, but rather through movements in the balance between groups, classes and elites in the state and in civil society. Though the European civilising process produced, over the long term, a greater degree of societal inter-dependence and a relative internal pacification of violence, Elias is quick to add that this is not the outcome of a linear process but an uneven and fragile one of group, class and elite struggles and conflicting rationalities. Throughout his life, furthermore, he worked on a theory of the 'decivilising process' whereby the collapse or suspension of constraints can be explained. Power fluctuates and is contingent for Elias, much as it is also for Castoriadis.

The unique appeal of his paradigm to current-day sociologists lies in the bond between modes of civility and patterns of state formation and the very longterm processes through which the bond emerged. Known also as figurational sociology, it gives an account of the structuring (or 'figuring') of behaviour and agency by the civilising process. There is one further important and relevant element of Elias's figurational sociology. He tracks the emergence of a European consciousness of civilisation (see also Bowden, 2007). According to his account, Europeans had - in a process of collective amnesia - eliminated all memory of the civilising process by the nineteenth century. In its place sat an ideological notion of civilisation which was the self-consciousness of the West:

It sums up everything in which Western society of the last two or three centuries believes itself superior to earlier societies or 'more primitive' contemporary ones. By this term, Western society seeks to describe what constitutes its special character and what it is proud of: the level of its technology, the nature of its manners, the development of its scientific knowledge or view of the world, and much more. (Elias, 1978: 3-4, emphasis in original)

Notwithstanding this important insight, Elias did not incorporate cultural factors into his explanation of the figuration of social structures or his theorisation of power. As far as the current argument is concerned, there is an even more significant gap. If Elias's figurational sociology of the civilising process does well in scrutinising endogenous and intra-societal dynamics of state formation and the taming of routine violence, it did not probe any dimension of the interaction 
of civilisations. None of the main phenomena he deals with are considered as coextensively instituted through the deep engagement of civilisations. In particular, the expansion of empires and variety of imperial orders finds no place. Yet, colonialism denotes a whole other side to violence and warfare. Europe's modern empires were two-sided states, being colonial and more or less dictatorial abroad and national and amenable to democratic pressures at home. Might not the impulses to restraint at home be counter-balanced by releases of violence in colonial environments? Whatever the answer to that question, outbreaks of imperial violence call for explanation, whether they take the form of repressive violence or inter-state wars. Other perspectives in studies of international relations focus on problems of international conflict and the exercise of kinds of 'soft power' - as, for instance, in the establishment of the international standard of civilisation (Gong, 1984). Gong's analysis would be relevant for an international elaboration of Elias's theory not because states were faithful to the international standard (as they were often not), but because of the normative threshold it set. It is relevant in its positive appropriation by nationalist movements seeking to end colonialism (Duara, 2001). They turned Europe's universal standard of civilisation and its normative tenets against Europe's global empires. Robertson shows that Elias's perspective could be pressed into partnership with Gong's (Robertson, 1992: 116-25). Even so, the absence of the international arena from Elias's analysis is a stark omission and, in this respect, his results are context-bound and thus tacitly Eurocentric (Arjomand, 2014b: 34). Where it traverses any of these topics (e.g. war) it does so in a one-sided fashion without clarifying vital exogenous influences.

None of this is to claim that the theory of the civilising process is closed to revision or internationalisation. Since the theory of the civilising process does not hypothesise civilisational unities in its examination of the impulses and logics of state formation, Elias's notion of power could be corrected and marshalled in a different methodology and with a different analytic. Different results would emerge, without attenuating his useful and original insights. Moreover, it is quite clear that there are other figurations of power with distinct civilising processes. Framed as international studies, comparative analysis can be carried out from within Elias-inspired figurational sociology. Studies of Singapore, Japan and the United States have done just that (on Japan, see Karlin, 2014). The extent to which imperial contexts of power and inter-civilisational interaction could be worked into figurational sociology remains to be seen.

Arnason is open to the examination of civilising processes in international contexts (Arnason, 2004, 2015) and he gives careful consideration to Elias's model and methodology. Arnason's version of civilisational processes brings valuable studies of inter-civilisational encounters to bear on some of the questions 
raised by Elias. A compelling interest in Benjamin Nelson, Marshall Hodgson and Williams McNeill took him towards a relational image of civilisations. As a practitioner of this approach, Arnason is a link between the third generation and the problematics of earlier comparativists, particularly Weber and Durkheim and Mauss. Since readers are less likely to be familiar with his work, the presentation of his ideas is longer. As he exemplifies the relational image by extending the findings of Nelson and Hodgson in particular, his work is an important precedent to the version of civilisational analysis argued for in Chapters 4 and 5 .

\section{Arnason's core questions}

Arnason's civilisational analysis matters for two reasons. To start with, his work matters as a point of orientation and innovation for the notion and historiography of inter-civilisational engagement I articulate and defend in Chapter 4 and Part II. In the remainder of this chapter, I outline Arnason's core questions and mark the shifts that have occurred in his approach. Having charted his oeuvre, I critically canvass perceived gaps in order to push his reconstruction of intercivilisational encounters towards an alternative conception of interactivity and connectedness.

As a second reason, Arnason's work matters in its own right for its relationship to the field. Arnason goes further than any other comparable thinker in reflecting on civilisational theory as a mode of historical and sociological analysis. The discipline of philosophy helps by raising key second-order questions of the field and paving the way for a hermeneutical focus on understanding. Through critique of enduring and unresolved conceptual difficulties and epistemological gaps he arrives at a critical assessment of comparative studies of civilisations and concludes that it is a paradigm-in-the-making capable of revising its theoretical formulations in light of empirical and comparative findings (2007). Arnason's own contribution ranges from creative theoretical fusion and detection of untreated empirical problems to theoretical and historical controversies and dilemmas. In a self-stylisation of his approach, he dubbed his 1990s research on Japan 'postWeberian' (1997a). The phrase appears less often later in his writings, but three premises remain in his meta-theoretical trajectory from that point: multidimensional analysis is the key to understanding 'civilisation' and 'civilisations'; culture and power are inter-related; and civilisations are created through intercivilisational encounters. Across the course of the development of his thinking, he has combined this early trajectory with a historicist position of being strongly 'for history', a contextualist position of being 'for regions', and a permanently provisional attitude towards theoretical, historical and empirical questions. 
Moreover, he develops a methodology best described as post-transcendental phenomenology, centring on a phenomenological concept of 'world' fashioned over the course of an intellectual career (see Adams and Arnason, 2016). With this methodology, he reconstructs Eisenstadt's 'cultural ontologies' via a reinterpretation of Weber as diverse cultural and inter-cultural articulations of the world. In his chief work Civilizations in Dispute, his agenda for ongoing inquiry is organised around the cultural, political and economic constitution of civilisations; in his words, 'meaning', 'power' and 'wealth' (Arnason, 2003). With this interpretivist and historicist agenda, he addresses four fundamental questions. What is civilisation? How are civilisations constituted culturally, politically and economically? In what ways are civilisations related to regions? How do historical contexts shape different civilisations?

The first question is foundational to the others and is the pretext of a turn to a relational image: how should 'civilisation' be conceptualised? The strong culturalist lineage in civilisational analysis should be assiduously avoided in answering the question (Arnason, 2011b: 109). Strong versions of 'identitarian' culturalism found in Spengler and Huntington uncritically reproduce images of closed civilisations. Following Dumont and the phenomenologists Jan Patočka and Maurice Merleau-Ponty, Arnason prefers inquiry based on interpretation and understanding over strong causal models of explanation produced in identitarian versions (2003: 65). Urging problematisation of conceptions that postulate the internal unity of civilisations, Arnason expounds a 'stronger emphasis on and better understanding of differences and differentiation' (2003: 5). It is, for example, noticeable that some civilisations generate more adaptable collective identities, while others are better at singularising internal cultures. Arnason's position lends credence to the conclusion that any hard-set integrationist images will do little to illuminate actual patterns. In fact, thorough and open-minded research on civilisations and their contexts should put into question 'a persistent tendency to take Western patterns and presuppositions for granted, rather than to re-think them in the light of comparative analysis' (1997a: 5).

With two further moves Arnason's position is set at a further distance from the integrationist image. First, borderland zones, moving frontiers and shared regions should be incorporated into a more capacious conception of civilisational dynamics (2007). In turn, this opens the way to an understanding of regionality with wider potential applications. How civilisations 'exist' in spatial terms becomes a problem of how regional frontiers effect collective identities. Moreover, the spatial existence of civilisations is also a problem of how civilisational dynamics influence regional patterns (Arnason, 2003: 31). A more capacious geography of civilisations that accounts for interstitial geographical spaces has the potential to resonate with other perspectives in history and post-colonial 
studies and to discern patterns of interaction and connection. Second, Arnason's notion of civilisational patterns portrays civilisations as more complex and diverse than previously believed (2004). Durkheim and Mauss's characterisation of civilisations as societies with a family resemblance is not sufficiently pluralistic for Arnason's liking (2003: 296-304). Too many world regions are multicivilisational to take Durkheim and Mauss's formulation at face value. With the notion of civilisational patterns, Arnason aims to better understand a host of civilisational components: multiple political centres, the organisation of imperial states and regional spheres of cultural or religious reach.

With these two moves Arnason turns to dimensions of power, meaning and wealth - the second question - in order to chart the encounters of civilisations. Arnason's particular non-functionalist understanding of power de-reifies this core concept. 'Power' is not a 'thing' that varies according to the quantity that a state, ecclesiastical or economic institution holds. For Arnason, power is constituted and mutates according to shifting patterns of culture. To be more precise, patterns of power and patterns of culture interact and define each other in a variety of ways. One civilisational complex will exhibit one particular set of patterns of culture and power. Twentieth-century Russia is an example (Arnason, 1993). Soviet power was influenced by historic interaction with both Central Asian and Western states, and with Western revolutionary traditions. Other constellations are quite different and reflect other sets of relationships of culture and power. As a civilisation, Japan, as a separate instance in a different context altogether, actively 'singularises' its model of power in encounters with a regional Sinic civilisation (Arnason, 1997a). Confronted with variety, the job is to judge on the basis of evidence compiled and scrutinised. According to Arnason, conflict, protest and movements are often found at work in shaping intermingled patterns of power and patterns of culture. A wholesale transfer of a set of patterns of power and patterns of culture is rarer, however (Arnason, 2003: 189). Institutions of power may be mobile, particularly with modern empires that trans-nationalise military force and administrative reach, while constraining the spread of cultural values of the core. In some civilisations, the creation of power occurs through expansion of cultural institutions. For instance, the extension of Islamicate civilisation throughout South-East Asia influenced state formation particularly in sixteenthcentury Indonesia and Malaysia, miles from the armies of the Safavid Empire.

Arnason analytically separates 'meaning' from socio-culture. He posits historically received 'multiple constellations of meaning' (2003: 294) or (following Nelson) 'cues' (2003: 149-57), which contour the cultural ground for interpretation, communicability, conflict, dissonance and reflexivity. 'Culture' fluctuates more than many other civilisational analysts think, according to Arnason. 'Cultural problematics' as horizons of meaning may frame political, economic 
and cultural interpretations, but they are not free-floating (2007). Nor are they entirely unstructured or non-structuring. A civilisation's potential for intercultural experiences and reflexivity is tested by encounters with other bodies of meaning. Two features distinguish his analytics of meaning and socio-culture from Eisenstadt's cultural ontologies. First is the heavy emphasis on the imaginary as a horizon of meaning. Through his theoretical reconstruction Arnason dissociates himself from neo-Weberianism (if not from Weber himself). Second, his post-transcendental phenomenology produces a hermeneutics of culture that minimises the difficulties of cultural determinism (Adams and Arnason, 2016). Cultures appear more dynamic, diverse and contingent, but are still contained by the imaginary.

'Wealth' is constituted on a more homogeneous plane, and thus it tends to exhibit tendencies towards integration more readily. Following the tracks of Braudel's history of capitalism, networks of wealth can be traced to the early modern expansion and intensification of trade. According to Arnason, any perspective on wealth generated from within civilisational analysis should recognise the novel problematisation of economic practices associated with modern capitalism. The processes involved with capitalism's institution were certainly not culture-free (much less meaning-free), even though they were trans-civilisational. In the twentieth century, emerging varieties of wealth are demonstrably more diverse than many political economists have thought. Theories of the 'new spirit of capitalism' mark out different varieties that precondition the domestication of capitalism in national and regional contexts (Arnason, 2005).

The intention of Arnason's multidimensional model is to produce a notion of a civilisational complex flexible enough to accommodate diverse institutional environments, cultural frames, geographies and forms of conflict. It leaves room for the legacy of inter-civilisational encounters to enter the picture. However, the composition of power, wealth and meaning in a specific context also structures how interactive a civilisation is in relation to others. This is an important presupposition for historical inquiry and I carry it over into Chapter 4 and Part II, in which inter-civilisational engagement is theorised and specific world regions are explored. More generally, I regard inter-civilisational encounters as an aspect of Arnason's model of civilisational analysis that is amenable to further revision.

Before proceeding to Arnason's historicist and regionalist outlook, some points of further distinction from Eisenstadt's comparative sociology seem apposite. Arnason's reconstruction proceeds by responding to the pressing questions put by Eisenstadt about modernity and civilisations. Differences surface, however. Where Eisenstadt is fixed on reconciliation between the body of research into Axial civilisations and the paradigm of multiple modernities, Arnason is far from confined by that problem. Arnason's option of a 
historicist treatment and critique of the Axial Age debate means that he can handle Axial civilisations as contingent on their historical age and makes no presumptions about the lasting impact of breakthroughs to reflexivity. The rest then becomes an empirical question and can be left to the results of ongoing research. No archetypes prefigure the unfolding of particular modernities in relation to formative civilisational legacies. The ambivalent turn to plural modernities and civilisations inaugurated by Eisenstadt and others in the 1990s is sharper in Arnason's programme because he is not constrained by a typology of macro-sociological formations (Wagner, 2012: 67-8). Moreover, he properly exercises historicist concerns by focusing on successive modernities, alternative modernities and possible series of civilisational developments in one geographical zone, rather than multiple modernities in an integrationist vein. Historical contingency is accorded more respect in his picture of civilisations by his introduction of hermeneutics into civilisational analysis (Adams and Arnason, 2016: 181).

Over time, Arnason's plea for historical perspective has grown, the third of his key questions. The fact that Arnason turns to specialist histories repeatedly to validate his theoretical suppositions shows how strong his quest for historical understanding is. Electing to count as one of a number 'who want to see civilisational analysis develop as a branch of historical sociology' (2014: 180), he is positioned against the uncritical use of typologies to evade careful research. Few generalisations can be made ahead of systematic research, and constant selfreminders of contingency in history are important when it comes to identifying empirical regularities in social formations, states or civilisations (Knöbl, 2011). On this view, the paradigm remains quite incomplete without a properly historical foundation.

On the back of this historical sensibility, Arnason's projects have headed in an increasingly historical direction. The projects can be grouped into three types of historical sociological analysis. The first type comprises investigative prolegomena into South-East Asia (1997b) and Byzantium (2000). The prolegomenon qualities of the two studies could be charged with failing to bridge the gap between theory and empirical application, but then this is only to bear out his point that much careful history is needed to validate civilisational arguments (Spohn, 2011: 29). The second type of project goes further. In edited collections of essays by specialists in Islamicate civilisation, Greece and Rome, Arnason and others prosecute key debates and air fresh arguments about historical and current assessments of the significance of major civilisations (Arnason, 2011a; Arnason and Murphy, 2001; Arnason et al., 2006). Arnason's own full-scale studies are the third type of project. He situates Soviet modernity in relation to different political traditions (1993), and Japan in relation to East Asia (1997a, 2002). 
The monographs on Russian-Soviet and Japanese civilisations are enough to represent the multi-civilisational regions in which Arnason's programme is most extensively operationalised. The Soviet experience brings specific components to the fore: a reworked history of imperial modernisation, engagement with Western dynamics (and to a lesser extent the Central Asian one) and traditions, and the fate of revolutionary Marxism in the context of Russia's long-term trajectory (1993). The Soviet Union inherited a 'composite civilisation' . At different times, the Russian state had experimented with Westernising strategies. The foundation of the Tsarist state was marked by a problematic relationship with autocratic Byzantine and Eastern Orthodox traditions. Its fortunes were shaped by conflicts with other states along the way, especially the Mongol invasion, war with Japan and the First World War. Three regimes were watersheds: Ivan the Terrible, Peter the Great and the Bolsheviks under Lenin. The key to understanding the Soviet state lies in tracing continuities with the Tsarist state and its traditions, in particular the elaboration of the 'Petrine imaginary' based on Peter the Great's modernisation-from-above. The radicalisation of Jacobinism occurred in juxtaposition to Tsarist colonisation of a limited public sphere, but, Arnason argues, it absorbed more of its opposite (1993: 55-69). Stalinist Russia, on this account, completed the fusion of imperial and revolutionary traditions and then fully Russianised the state apparatus.

Two observations situate this study of the early 1990s in a developing lineage. First, Arnason balances his historicist position on the factors of historical background and interpretive agency. Traditions loom particularly large in the Soviet case, but with the qualification that 'if the exploration of this background begins with a brief discussion of the Russian state and its trajectory, there is no suggestion of collapsing all other factors into the long-term dynamic of state formation' (1993: 28). This is an example of Arnason's hermeneutical emphasis on interpretation precluding a slide into linear evolutionist determinism. Second, the meta-theoretical categories of Arnason's programme were not formed at the time. Some important features of his later theoretical scaffolding are plain, however. His cautious reference to the Axial Age theses and the encounters of civilisations foreshadow his later theoretical approach.

Arnason's model of civilisational analysis is more formed in his historical sociology of Japan. Japan is a dual civilisation. On one hand, its ontological orientations are to its own traditions. On the other hand, it responds as a civilisation to exemplary foreign constellations. Its historical experience is punctuated by momentous encounters with China and the West. The capacity of Japanese civilisation to differentiate itself as both a civilisation and a state has defined its trajectory. Japanese experience has also been marked by a propensity to carefully read and respond to the external environment. 
Successive regimes have met external challenges with a range of responses, from strategic withdrawal to intensive relations. In the external environment, the stand-out civilisation is Chinese. Yet claims about the continuities of the Confucian East Asian sphere and Japan's incorporation into it have been overstated (Arnason, 1997a: 377-9). The break with China in the middle of the nineteenth century was a creative crisis activating traditions that checked Confucianism. More originality can be attributed to the post-1868 Meiji period in respect of consolidation of civilisational patterns. Arnason diverges markedly from Eisenstadt on this point (Eisenstadt, 1996). The Meiji break was too pointed to assume the degree of continuity that Eisenstadt does. Japanese modernity is a new chapter, but not one in which previous patterns were dissolved or traditions abandoned altogether. The ability of the regime to commence imperial expansion in the late nineteenth century based on its previous peripheral status in Asia - and to extend this further in the Showa era - was unparalleled, even if the over-extension of its military plans resulted in failure (1997a: 486-91). It signalled the imagination of new civilisational capacities. Arguably, these have been more successfully marshalled by the post-war developmental state that has reinvented capitalism (1997a: 475-502). Japan's capitalism is the problematic least addressed by Arnason beyond his initial insights (Smith, 2014c). More could be done to emphasise the modernity of Japanese capitalism. Yet Arnason does enough to illustrate the creative powers of Japan's capitalist form and how singular the developmental state has been.

Both in-depth monographs turn up distinct civilisational patterns and histories. Arnason reaffirms regional contexts in order to validate the proposition that civilisational patterns are more on the unique side than most analysts admit. He does more than endorse the study of different world regions. He begins the work of incorporating regionality - the fourth key question - as a problem itself into the civilisational paradigm. Arnason starts with existing concepts of regions and regionalism (2003: 314-22). His formula focuses on different relationships that regional identities have with civilisational impulses. Picking out the most pertinent examples of regional civilisations will not do when a better strategy is on offer. That strategy is a delineation of how particular 'civilisations are more regional than others, and some regions are more civilisational than others ... [T] he task of civilisational theory is to account for the spectrum of variations on both sides, rather than to single out the most congruent cases' (2003: 315). Arnason's strategy counters tendencies to reification of regions as stable geographies by casting 'both sides' as dynamic. So, while approximately one hundred regions are coextensive with civilisations, it is the most illuminating mixtures that require analysis, including less likely 
candidates such as South-East Asia (Adams and Arnason, 2016: 170). In contrast, the relationship between civilisation and region in Islamicate civilisation is weaker and has been cause for historians to be more cautious than in the past (Arnason et al., 2006).

Looking at macro-regions might be another mode of assessment of region and civilisation. In a collaborative collection of essays not covered above, Arnason and Wittrock explore the late medieval period across Eurasia (2004). In this collection, comparative sociologists and historians show the exceptional historical sensibilities characteristic of the sociological imagination. Even more noticeably, they exercise regional sensibilities; that is, deep appreciation of regional, interregional and trans-regional contexts. A consensus gels around two conclusions. First, there is enough to justify continued research into congruencies of region and civilisation in Eurasian experiences. Second, global history should include inter-civilisational encounters with Eurasia in its log of central dynamics. This brings in Arnason's leitmotif: inter-civilisational encounters, which is where the historical and regional sensibilities meet.

What distinguishes inter-civilisational encounters from other kinds of linkage? Arnason builds on conceptions of inter-civilisational encounters developed by Nelson, Hodgson and Jaroslav Krejci (Arnason, 2003: 187-94). Fleshing out what he perceives to be the underdeveloped aspects of Nelson's thinking, Arnason elaborates a notion of cultural problematics from Nelson's cues on Europe's encounters, and then suggests that this could have been taken further via comparison with other civilisations (2003: 147-54). The most decisive element is evidence of 'mutually formative relations between civilisational complexes' (2003: 287). Arnason departs from Nelson by asking what makes specific civilisations more open to confrontation with other and different socio-cultural formations. Arnason attributes special importance to encounters in multicivilisational zones. Another point of departure is to bring in economic and political as well as cultural factors (2003: 289-92).

The interaction of civilisations is best viewed through the prism of a 'phenomenology of encounters' (2006: 39), or the hermeneutical transfer, absorption, circulation or exchange of elements. Careful reconstructions of specific cases serve to clarify major contentions. A brief sketch of inter-civilisational encounters for India and Japan reveals Arnason's method. Blockages to the benefits from India's encounter with Ancient Greece came from a lack of reflexivity in both civilisations in respect of each other, but particularly so on the part of Indian civilisation. By way of contrast, India's encounter with the West resulting from British colonialism revealed Indian reflexivity much more so than for the British side (2006: 42-5). A contrast with these two encounters is the depth of the twosided encounter with Islam that occurred in India's early modernity. Comparison 
of the three encounters in India's past shows a 'continuum' of inputs into India's cultural memory (2006).

Arnason's reconstruction of the Japanese context illustrates a different continuum. Japan is 'emergent and relational' and especially given to inter-civilisational encounters (Arnason, 1997a: 80). Throughout its history, Japanese self-belief in a separate civilisation proved important. Encounters with China-centred East Asia seem to contrast with the marked self-seclusion of the Tokugawa era from 1600. Yet the latter phase can also be seen as an orientation to events, or rather a distancing from East Asia as part of restructuring the domestic social order. Japan's cultural orientation occurred at a distance, and in the latter part of the Tokugawa period. A noticeable eighteenth-century intellectual current of Western learning established a foundation of knowledge that was a pretext to the Iwakura Mission, which involved a comprehensive programme of learning about other states and cultures launched during the full-scale encounter with the West across the 1860s and 1870s. Japan's self-shaping continued to be linked to changes in the international arena from this point. The whole civilisation's history is composed of recurrent swings between the regional context and an internal sense of uniqueness.

In Arnason's summation of the histories of India and Japan, inter-civilisational encounters punctuate the past. Arnason argues, contrary to Eisenstadt, that long-term trajectories are uneven and that connections with past civilisations are mainly made through interpretations of cultural, political and economic doctrines, patterns and models. Not in thrall to the problematic of cultural ontologies - but also far from denying their importance - Arnason seeks to uncover the interpretive transformation of civilisational origins. He is especially interested in the transformative moment of inter-civilisational encounters, which always have an interpretive dimension. Even though civilisational histories are generally discontinuous, inter-civilisational encounters are distinguished by their impact and durability.

But this raises questions about the status of inter-civilisational encounters and underlying connections between societies, cultures and states. What precedes encounters, apart from the social imaginary significations that make interaction possible? In a passage that points to the kind of economic ties that constitute inter-civilisational engagement as I outline it in Chapter 4, Arnason points to the nub of the problem: 'it is not enough to point to the omnipresence and variety of economic contacts: only major turning-points with far-reaching consequences on a civilisational scale will fit the term' (2003: 289). The statement is at odds with the notion of inter-civilisational engagement propounded in these pages. But it clarifies a point of disagreement, which revolves around the distinction between the 'omnipresence' of contacts and 'major turning points'. It is methodologically 
difficult to disentangle significant encounters from the forms of engagement with consistent certainty. However, in a later essay (2007), Arnason offers a tentative way forward. He responds to new scholarship on entangled histories and modernities - which pointed to the complexity and depth of connectivity in the modern global order - by asserting that a map of inter-civilisational encounters can help differentiate specific scenarios in the global age. That this is a helpful step is not in doubt, but it does not give recognition to the depths of connections. For the present author, it suggests that connectivities are obligatory subject matter for civilisational analysis.

Arnason's account of the West's prominence in modernity can serve to illustrate my point. To begin with, credit is given to inputs from Islamicate civilisation via inter-civilisational encounters between the two (Arnason, 2006). However, it still does not give enough due to contributions to Europe from other civilisations in terms of the overall range of networks, bonds and links, including the more routine and less visible kinds of inter-civilisational engagement. FernándezArmesto shows the problem in a different complexion when he states:

European culture ... is then seen to have been at least as much the product of influences exerted from east to west as the other way round: the spread of farming and of Indo-European speech; the Greek and Phoenician colonisations; the migrations of Germans and Slavs; the coming of Christianity, that Oriental mystery-religion which Europe had appropriated; the steppeland invasions; the Ottoman pressure; the spread of what used to be called 'international communism,' which has lost its empires but left its mark. And all of these movements have to be seen against the background of the long-constant flow of technology and ideas from farther east: Arab sciences, Indian mathematics and spirituality, and Chinese inventions. The importance of these in the making of Europe is still only beginning to be acknowledged in the West, but the evidence of it is all around us. (Fernández-Armesto, 2001: 311)

Fernández-Armesto makes conspicuous the sense of the volume of inputs over the longue durée in a manner hard to refuse. European exceptionalism dims in the face of the patterns of engagement that are formative of the cultures of northwestern Eurasia. Taking a more international perspective seems more promising. To the long-term impulses of Eastern inputs we can add the historic conjoining of the Western hemisphere and Eurasia through the European conquest of the Americas. The era was a watershed in which early modernities coalesced in approximately the same time frame and joined an inter-regional expansion of connections. Without doubt, that problematic of interaction as part of the constitution of the modern world has been a concern to other historians, ranging widely from Chris Bayly and Kenneth Pomeranz to Enrique Dussel, and from J. G. A. Pocock and Anthony Pagden to world systems analysis, James Blaut, 
Jack Goody and de-colonial historians. Integration of pre-modern global connections remains as yet more the domain of world history and economic history than civilisational analysis (Inglis, 2010), a matter of great challenge to the latter.

How could comparative and historical sociology offer more to a reconstruction of connected early modernities? Arnason's entreaty to civilisational analysis to emphasise agency and the historical and dynamic nature of civilisations itself foregrounds the entanglements of civilisations (Knöbl, 2006a). Nelson and Arnason's relational models could be strengthened by retraining the analytic focus on the depth of entanglement that historical agency carries. If framed as such, the density of connections would, however, undermine the exceptionalism claimed for any civilisation. Salvatore submits a similar argument when he proposes that Arnason's triad of power, meaning and wealth taken to its logical conclusion would be elaborated as trans-civilisational logics (2007). The social philosophies of other civilisational bases that Arnason credits with a part in the crystallisation of the Western tradition contribute more, as far as Salvatore is concerned. Islamicate civilisation - and possibly others as well - are fields 'of ongoing inter-civilisational processes and transcivilisational encounters' with a worldwide impact (2007: 331). Comparative and historical sociology has not realised the vitality of trans-civilisational dynamics, perhaps because 'the spirit of "Western exceptionalism" does not yet appear to be absorbed and neutralized in the comparative perspective of civilisational analysis' (2007: 331). Civilisations are produced by interconnected processes and should feature as such, rather than as fragments of a complex institution of Western modernity. Contemporary civilisational analysis has not yet found the right stress on multivalent integration.

Re-scoped in this way, contemporary civilisational analysis could leave behind integrationist definitions and study neglected societal figurations that have not previously made the grade as 'high civilisations', but which are embedded in inter-civilisational engagement and therefore subject to the processes of trans-civilisational reconstruction. This would pose different questions about power, as well as looking at fresh figurations not normally examined as civilisations. Arnason for one is receptive to suggestions of further revision. In his view, civilisational analysis cannot exhaust understanding (Arnason, 2010) and 'should not be mistaken for an attempt to subsume everything under civilisational categories' (2011b: 117). When couched in these terms, civilisational analysis appears responsive to criticisms from within and from without. There is a small critical reception of Arnason's work. A number of the criticisms highlight areas where civilisational analysis at large has even more gaps. Two areas stand out: the status of new world formations and the underdeveloped field of colonial modernities. 


\section{Critical reception}

A first area that critics focus on relates to those societies and cultures omitted from the scope of analysis. Arnason has yet to incorporate new world and oceanic theatres of civilisations substantively in deliberating on his core questions, or to look at indigenous civilisations in any detail. More generally, contemporary civilisational analysis has not incorporated either in its paradigm (see Rundell, 2004). Given the interest Arnason shows in Durkheim and Mauss with their exploration of Pacific, Aboriginal Australian and pre-Colombian civilisations, one would have thought that this might be a frontier of deeper interest, so this is a little surprising. But there are notable acknowledgements of the gaps and further invitations to fill them. The achievements and limiting boundaries of Eisenstadt's comparative essay on the first American modernities are a starting point (Arnason, 2010: 11-12, 2011b: 117). Noting that Eisenstadt draws into relief the religious premises of Euro-American colonialism, Arnason points out that detailed scholarship challenges the results of his analysis (Blokker and Delanty, 2011: 127-8). Too many complexities are highlighted in the historical and sociological literature on the Americas to leave Eisenstadt's intended research strategy untouched. Marking out the respective positions of Eisenstadt and those who picture multiple American regions with multi-civilisational influences (including the present author), Arnason argues that a more nuanced mode of analysis is needed.

When it comes to indigenous civilisations in the Americas, however, Arnason's own impressions are open to question. Noting that a fuller assessment of the status of indigenous cultures would have to await later consideration, Arnason estimates that only two cultures out of the extended continuum of pre-Colombian societies could qualify as civilisations. There is limited evidence of inter-civilisational encounters between the Incan and Mexica (Aztec) civilisations. True enough, although the detail of connection between the two might increase in the hands of future archaeologists and philologists. Considered from the point of view of inter-civilisational engagement, however, the picture looks more nuanced. Evidence from the growing scholarship of the pre-Colombian Western hemisphere (and after colonial intrusion) points to wider and denser regional networks of movement of people, goods, contacts and ideas; in short, a hemisphere of inter-civilisational engagement in which contacts are thicker than has been previously thought has yet to have an impact on civilisational analysis or theory (Sabloff and Lamberg-Karlovsky, 1975; Trombold, 1991). In part, this has been an empirical matter and in part it is a theoretical and epistemological one. The question of connectedness of pre-Colombian civilisations may now be re-problematised. The rise of indigenous consciousness since the 1970s has led 
to cultural and political association between first peoples up and down the two continents of the Western hemisphere. Between constructions of shared indigenous memory and revival of cultural traditions, living civilisations with living cosmologies have constituted themselves as collective actors. The last word does not lie with neglect, however, but with a reminder about the provisional character of analytic evaluations. When asked about Africa, Arnason replies, 'There is no a priori reason why the paradigm should not be applicable to other parts of the world but each case will raise specific problems' (Blokker and Delanty, 2011: 127). Obviously, this should also be taken as an invitation to further exploration of new world regions, including oceanic ones.

Colonial modernities are a second area of critical response. Arnason's engagement here is pithy in theoretical terms. However, his treatment of historical specifics amounts more to a series of evocative suggestions for specialists than to a sustained attempt at a larger fusion. His theoretical engagement can be summed up briefly. Arnason calls for an altogether different theoretical strategy and methodology to unpick Eurocentrism's traditions. Arguing that the 'metahistorical meaning' of visions of East and West have been amassed through a long but twisting history of image-making, he points to the very incomplete nature of deconstruction of Orientalism. Post-colonial deconstruction is incomplete, but so too are deconstructive projects of civilisational analysis, about which Arnason is plainly more optimistic. Post-colonial critique is far from fully formed, however. Arnason indicts post-colonial thought itself for failure to properly analyse actual colonial modernities (2003: 323-9). Suggestive pointers on North Africa, British India, the Near East and Thailand clarify the extent of the challenge. Though he discusses East Asia, Arnason does not consider published works explicitly thematising East Asian colonial modernities. They nonetheless present some key arguments distinct from Arnason's version of civilisational analysis. East Asian historiography is urged to rethink relationships between problematics of colonialism and modernity (Barlow et al., 1997). Nationalist historiography is particularly unfit for the task of pulling together colonialism, modernity and nationalism to reconsider inter-relationships of the two, as is the existing Subaltern Studies tradition also. Above all, scholars of East Asian colonial modernities emphasise a mode of history not absorbed with national or single societies and able to link the formations in question. The results of the projects on colonial modernities may have been piecemeal, but they potentially supplied momentum for further development. However, interest in colonial modernities as such was, at best, slow at the end of the 1990s. There can be little doubt that colonial modernities would require more attention to progress new insights. But other paradigms of comparative sociology and relational 
history could expand the problematics formulated by research on colonial modernities. Any chance of reconciling Arnason's suggestions with established directions (such as Toni Barlow's) is subject to the general relations between contemporary civilisational and post-colonial analysis. There is not much optimism about this, but in the next chapter proposals for potential meeting points between the two fields are made.

\section{Conclusion}

This chapter critically summarises the positions of three representative figures of contemporary civilisational analysis in order to delineate insights and shortcomings. They each are heirs to different images of civilisations developed in classical sociology and by early world historians. Each reconstructs the work of their predecessors in their own way. There is room still for further interrogation of the precepts of contemporary civilisational analysis. In the versions included in this chapter, modern colonialism is marginal and, at times, empires are absent. Furthermore, the integrationist image in particular emanates an inherited impression of civilisations as relatively stable and separate unities that in itself displaces the wide span of contacts, connections and exchanges between social formations. As far as my version of contemporary civilisational analysis is concerned, this is the significant shortcoming. It draws attention away from flows of migration, economic movements, cultural transmission and adaptation and the redevelopment of models of statehood. There are other gaps. The relationship of civilisations and economies do not receive specific attention either - something of a puzzle given that they concerned Weber, Mauss and Durkheim (Swedberg, 2010). More precisely, capitalism as a modern social formation interacting with civilisations is noticeably lacking. Arnason is an exception in this regard. He has a more developed theorisation of capitalism and civilisation, with basic categories of wealth and money in place. More may yet emerge in his oeuvre by way of a defined direction about this particular problematic. However, capitalism and the international arena are also the subject matter of paradigms that partly rival civilisational analysis, partly share intellectual space with it and are therefore partly responsive to it. Globalisation studies, Marxism and post-colonial perspectives are three paradigmatic alternatives to civilisational analysis. Their interface with debates on civilisations reveals dissonances, but also common spaces in which agonistic engagement around common problematics might be possible. How that could be so is the focus of the next chapter. 